International Journal of Current Advanced Research

ISSN: O: 2319-6475, ISSN: P: 2319-6505, Impact Factor: 6.614

Available Online at www.journalijcar.org

Volume 7; Issue 4(J); April 2018; Page No. 11970-11973

DOI: http://dx.doi.org/10.24327/ijcar.2018.11973.2091

Research Article

\title{
INCREASING INCIDENCE OF MULTIDRUG RESISTANCE AMONG CA-MRSA CAUSING SKIN AND SOFT TISSUE INFECTIONS: A CASE SERIES
}

\author{
Subhra Saha*, Purbasha Ghosh, Gadadhar Mitra and Soumen Saha
}

Department of Microbiology, Burdwan Medical College, India

\begin{tabular}{|c|c|}
\hline A R T I C L E I N F O & A B S T R A C T \\
\hline Article History: & Human commensal Staphylococcus aureus has become one of the important reason of skin \\
\hline Received $17^{\text {th }}$ January, 2018 & and soft tissue infections (SSTIs) today. Among them methicillin resistant Staphylococcus \\
\hline Received in revised form $26^{\text {th }}$ & $\begin{array}{l}\text { aureus (MRSA) play signiticant role in these SSTIs and some of them are becoming } \\
\text { multidrug resistant. Although multidrug resistant strains of these MRSA isolates are more }\end{array}$ \\
\hline $\begin{array}{l}\text { February, } 2018 \text { Accepted } 9^{\text {th }} \text { March, } 2018 \\
\text { Published online } 28^{\text {th }} \text { April. } 2018\end{array}$ & $\begin{array}{l}\text { multidrug resistant. Althougn multidrug resistant strains of these MRSA isolates are more } \\
\text { prevalent in healthcare associated skin and soft tissue infections (SSTIs) but now a days }\end{array}$ \\
\hline & $\begin{array}{l}\text { they are increasingly reported in those SS Is that are associated with community settings. } \\
\text { Here we presented a case series about increasing incidence of multidrug resistance among }\end{array}$ \\
\hline Key words: & CA-MRSA causing skin and soft tissue infections (SSTIs). \\
\hline
\end{tabular}

SSTIs, Multidrug resistance, CA-MRSA,

Pyogenic lesion, Wound infection.

Copyright $\bigcirc 2018$ Subhra Saha et al. This is an open access article distributed under the Creative Commons Attribution License, which permits unrestricted use, distribution, and reproduction in any medium, provided the original work is properly cited.

\section{INTRODUCTION}

Staphylococcus aureus is the most commonly isolated human bacterial pathogen that causes a wide variety of infections, ranging from mild skin and soft tissue infections to serious infections such as sepsis and toxic shock syndrome, that can be fatal. Skin and soft tissue infections (SSTIs) are the most frequent forms of the disease which include infections of skin, subcutaneous tissue, fascia and muscle.These infections encompass a wide spectrum of clinical presentations ranging from mild infections such as pyoderma to rapidly progressive necrotizing fasciitis (Lopez et al., 2006).

It is well established that, at any given time, 20-40\% of the adults are colonized with Staphylococcus aureus (Collee et al., 1996). Although colonization typically precedes infection, relatively few colonized individuals develop staphylococcal infections. Some members of Staphylococcus aureus play a significant role in these infections and they are termed as methicillin resistant Staphylococcus aureus (MRSA).

MRSA causes illness through the production of numerous cell surfaces and secreted virulence factors. The disease is facilitated by its propensity to develop resistance to multiple antibiotics such as penicillin, other $\beta$ lactam drugs and cephalosporin classes of antibiotics. In addition, they are often resistant to many other classes of antibiotics (Borriello et al., 2005; McGeer et al., 1991).

*Corresponding author: Subhra Saha

Department of Microbiology, Burdwan Medical College, India
Many of these isolates are becoming multidrug resistant and they are susceptible to glycopeptide antibiotics such as vancomycin and oxazolidinone group of antibiotics such as linezolid (Mehta et al., 1998; Moellering, 2003).

MRSA infections have usually been associated with exposure to health care settings, but they have recently been identified in people without traditional risk factors such as prolonged hospitalization, poor infection control measures, indiscriminate and irregular use of antibiotics, lack of awareness, receipt of antibiotics before coming to hospitals and other co-morbid conditions such as diabetes, AIDS, chronic renal failure and chronic pulmonary diseases which bring them into contact with healthcare settings. These infections have been called community-associated MRSA (CA-MRSA) (Anupurba et al., 2003; Fridkin et al, 2005; Huang et al., 2006).CA-MRSA was first described in the 1980s in drug users and in the late 1990s the epidemic emerged in persons without antecedent healthcare exposure that became a major concern worldwide (CDC, 2003; Millar et al., 2007; Naimi et al, 2003).

MRSA infections are a problem across the whole health economy today and have been shown to be associated with a poorer outcome and higher mortality than similar infections caused by methicillin-sensitive strains of Staphylococcus aureus (Cosgrove et al., 2003; Whitby et al., 2001).

\section{Case series presentation}

\section{Case 1}

A 35-year-old male, a known diabetic who was on antihyperglycaemic medication irregularly came to Emergency ward of Burdwan Medical College and Hospital with chronic 
ulcer which presented on upper inner portion of thigh. Later he was admitted to Dermatology ward. The ulcer appeared 9 months ago as a small lesion that increased gradually in size with time. He also gave history of severe pain in thigh since last 2 days. His pulse was 94/min and his blood pressure was 120/80 mm Hg. His systemic examination was within normal limits. His laboratory investigations showed haemoglobin$12.9 \mathrm{gm} / \mathrm{dL}$, WBC count- $13500 / \mathrm{mm}^{3}$, neutrophill count $-82 \%$ and platelet count-2.5 lakhs $/ \mathrm{mm}^{3}$. His sugar profile was as follows: fasting-220 mg/dL, and post prandial $2-260 \mathrm{mg} / \mathrm{dL}$. The Gram stained smear of wound swab showed Gram positive cocci in clusters. The organisms were recovered in pure culture on blood agar after 24 hours and the colonies were round, convex and 1-4 $\mathrm{mm}$ in diameter surrounding with zone of beta-haemolysis. Organisms were also found to be nonmotile, catalase positive, coagulase positive, oxidase negative, DNase positive, blood agar haemolysis positive and mannitol fermenters. They were diagnosed as Staphylococcus aureus based on microscopy and biochemical characteristics. The antimicrobial susceptibility was determined by Kirby-Bauer disc diffusion method on nutrient agar as per the Clinical and Laboratory Standard Institute (CLSI) guidelines. The isolates were resistant to amoxicillin, ciprofloxacin, erythromycin, cefoxitin and amikacin and they were sensitive to vancomycin and linezolid.

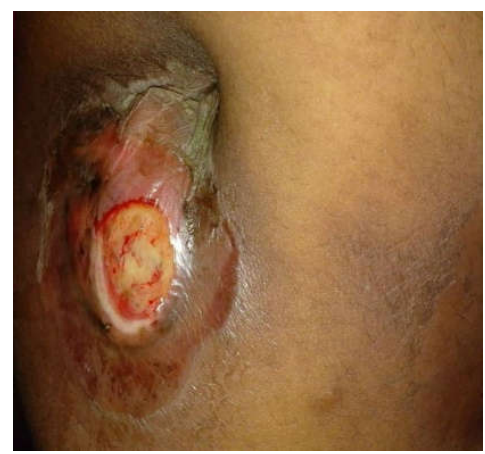

Figure 1: clinical image of patient showing wound on upper inner portion of thigh.

\section{Case 2}

A 51-year-old man visited Dermatology Outpatient Department (OPD) with the complaint of chronic non-healing ulcer on lateral portion of lower leg for last 15 months. There was no previous history of diabetes. On examination, the ulcer was approximately $9 \times 7 \mathrm{~cm}$ and it involved peroneus brevis muscle on lateral compartment of lower leg. The surface of ulcer was wet but there was no foul odour from the lesion. On investigation, patient's fasting and post prandial blood glucose level were $196 \mathrm{mg} / \mathrm{dL}$ and $240 \mathrm{mg} / \mathrm{dL}$ respectively. X-Ray of the lower leg did not reveal any bony involvement due to lesion. Laboratory test result revealed haemoglobin-12.4 $\mathrm{gm} / \mathrm{dL}$, WBC count $-13000 / \mathrm{mm}^{3}$, neutrophill count $-79 \%$ and platelet count-1.3 lakh/mm $\mathrm{mm}^{3}$.
Initially specimen was collected from the ulcer by means of sterile swab and aerobic bacterial culture and Gram staining were done. On Gram stain, Gram positive cocci in clusters were observed. The isolated organism was non-motile, nonspore forming, catalase positive, coagulase positive, oxidase negative, DNase positive, Blood agar haemolysis positive and mannitol fermenters. The isolate was identified as Staphylococcus aureus on the basis of microscopic findings and biochemical characteristics. The antimicrobial susceptibility test was performed by Kirby-Bauer disc diffusion method on nutrient agar as per the Clinical and Laboratory Standard Institute (CLSI) guidelines. The isolate showed resistance to amoxicillin, ciprofloxacin, erythromycin and cefoxitin and showed sensitivity to vancomycin, linezolid and amikacin.

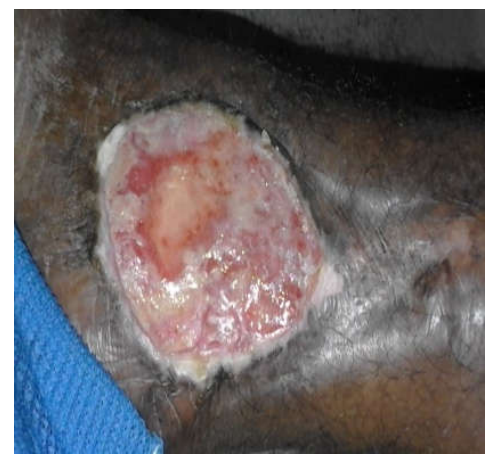

Figure 2: Clinical image of patient showing pyogenic lesion on lateral portion of lower leg.

\section{Case 3}

A 53-year-old male non-diabetic patient was admitted to Dermatology ward with a chronic wound on anterior portion of lower leg since last 11 years with mild pain since last 4 days. Patient was a resident of a rural area in Burdwan and was being treated by a private medical practitioner there. On general clinical examination his pulse was $87 / \mathrm{min}$ and his blood pressure was $110 / 80 \mathrm{~mm} \mathrm{Hg}$. In leg X-ray and ultrasonography there was no report of osteomyelitis. Further laboratory examination revealed his sugar profile was within normal limits. In addition, laboratory tests showed haemoglobin-11.2 gm/dL, WBC count-14000/. $\mathrm{mm}^{3}$ and neutrophill-85\%, platelet count-3.2lakh/ $\mathrm{mm}^{3}$. Microbiological exploration was done in Bacteriology laboratory of Burdwan Medical College. Gram stain showed Gram positive cocci in clusters. Based on biochemical characterization the organism was non-motile, catalase positive, coagulase positive, oxidase negative, DNase positive, blood agar haemolysis positive and mannitol fermenters that was identified as Staphylococcus aureus. The antimicrobial susceptibility test was done by Kirby-Bauer disc diffusion method as per the Clinical and Laboratory Standard Institute (CLSI) guidelines.

Table: Summery of cases

\begin{tabular}{|c|c|c|c|c|c|c|}
\hline \multirow{2}{*}{ Age/Sex } & \multirow{2}{*}{ Complaint } & \multirow{2}{*}{ Site of lesion } & \multirow{2}{*}{ Duration } & \multirow{2}{*}{ History } & \multicolumn{2}{|c|}{ Antimicrobial susceptibility } \\
\hline & & & & & Resistant & Sensitive \\
\hline $35 / \mathrm{M}$ & $\begin{array}{l}\text { Wound on thigh } \\
\text { with pain. }\end{array}$ & $\begin{array}{c}\text { Upper inner } \\
\text { portion of thigh. }\end{array}$ & 9 months & $\begin{array}{c}\text { Diabetes (Irregular } \\
\text { medication) }\end{array}$ & AMX,CIP,ERY,CX,AMK & VAN,LNZ \\
\hline $51 / \mathrm{M}$ & $\begin{array}{l}\text { Pyogenic lesion } \\
\text { without any pain. }\end{array}$ & $\begin{array}{l}\text { Lateral portion of } \\
\text { lower leg. }\end{array}$ & 15 months & 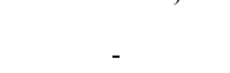 & AMX,CIP,ERY,CX & $\begin{array}{l}\text { VAN,LNZ, } \\
\text { AMK }\end{array}$ \\
\hline $53 / \mathrm{M}$ & $\begin{array}{l}\text { Leg wound with } \\
\text { mild pain. }\end{array}$ & $\begin{array}{l}\text { Anterior portion of } \\
\text { lower leg. }\end{array}$ & 11 years & - & AMX,CIP,ERY,CX,AMK & VAN,LNZ \\
\hline
\end{tabular}

Key: AMK: Amikacin; VAN: Vancomycin; ERY: Erythromycin; LNZ: Linezolid; CX: Cefoxitin; AMX: Amoxicillin; CIP: Ciprofloxacin 
Isolated organism was resistant to amoxicillin, ciprofloxacin, erythromycin, cefoxitin and amikacin and was sensitive to vancomycin and linezolid.

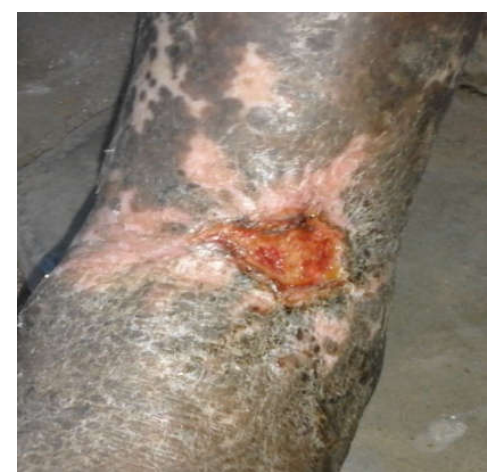

Figure 3: Clinical image of patient showing wound on anterior portion of lower leg.

\section{DISCUSSION}

The emergence of antimicrobial resistance and its rapid spread among pathogenic bacterial isolates are considered as grave threats to the public health worldwide. During the last few decades there has been a dramatic change in the epidemiology of community onset infections caused by MRSA. The rates of CA-MRSA (methicillin resistant Staphylococcus aureus) infections have increased in recent years in adult population and have also been reported in healthy adults who lacked traditional risk factors for acquisition of MRSA. Multiple reports of community-associated MRSA (CA-MRSA) infections have been reported in patients who lack the above risk factors (Beggett et al., 2003; Begier et al., 2004; Campbell et al., 2004; CDC, 2003).

Diagnosing the exact extent of the disease is critical for successful management of the patients of skin and soft-tissue infections (SSTIs) (Stevens et al., 2005). The minimum diagnostic criteria are erythema, edema, warmth, and pain or tenderness. The affected area may also become dysfunctional (e.g. hands and legs) depending on the severity of the infection. A patient's co-morbidities (e.g. diabetes mellitus and AIDS) can easily transform a normally mild infection into a rapidly advancing threat to life (Deresinski et al., 2005).

As CA-MRSA continues to emerge, monitoring its effect on therapy and whether clinicians are responding appropriately will be helpful. However, many studies confirmed that altering policy or antibiotic rotation potentially decreases the incidence of infections with antibiotic resistant bacteria (Kheder et al., 2010).

\section{CONCLUSIONS}

Today multidrug resistance among Gram positive bacteria such as MRSA is one of the major health problem that affects the whole world. Community-associated MRSA (CA-MRSA) has become increasingly important as a cause of skin and soft tissue infections (SSTIs), particularly in patients presenting to emergency and outpatient departments. As multidrug resistant MRSA infections have been on the rise in the community setting, the development of empirical antimicrobial therapeutic strategies for SSTIs has become more problematic.

\section{Acknowledgements}

We the authors would like to thank all the hospital and laboratory staffs for helping in sample collection and use of laboratory facilities.

Conflicts of interest

There are no conflicts of interest.

\section{References}

1. Lopez FA, Lartchenko S, "Skin and soft tissue infections", Infect Dis Clin North Am, 2006; Vol. 20, No. 4,pp.759-72,v-vi.

2. Collee JG, Fraser AG, Marmion BP, Simmons A,"Mackie and McCartney Medical Microbiology", Chapter 6. Tata McGraw Hill Publications; 1996; Vol.6, pp. 380-88.

3. Borriello SP, Murray PR, Arnold H,"Topley and Wilson's Microbiology and Microbial infections : Bacteriology", ASM press, 2005 ; Vol 10, pp. 769-70.

4. McGeer A, et al.,"Defintions of Infection for Surveillance in Long-Term Care Facilities", American Journal of Infection Control, 1991; Vol. 19, No. 1, pp. 1-7.

5. Mehta P, Rodrigues C, Sheth K, Jani S, Hakimiyan A and Fazalbhoy N, "Control of Methicillin Resistant Staphylococcus aureus in a Tertiary Care Centre - A Five Year Study", Indian J Med Microbiol, 1998; Vol. 16, pp. 31-34.

6. Moellering RC,"Linezolid: the first oxazolidinone antimicrobial”, Ann Intern Med, 2003; Vol. 138, No.2, pp.135-142.

7. Anupurba S, Sen MR, Nath G, Sharma BM, Gulati AK and. Mohapatra TM,"Prevalence of Methicillin Resistant Staphylococcus aureus in a Tertiary Care Referral Hospital in Eastern Uttar Pradesh", Indian $J$ Med Microbiol, 2003; Vol. 21, No. 1, pp. 49-51.

8. Fridkin SK, Hageman JC, Morrison M, Sanza LT, Como-Sabetti K, et al., "Methicillin resistant staphylococcus aureus disease in three communities", $N$ Engl J Med, 2005; Vol. 352, No.14, pp. 1436-1444.

9. Huang H, Flynn NM, King JH, Monchaud C, Morita M and Cohen SH,"Comparisons of CommunityAssociated Methicillin-Resistant Staphylococcus aureus (MRSA) and Hospital-Associated MSRA Infections in Sacramento, California", J Clin Microbiol, 2006; Vol.44, No.7, pp.2423-2427.

10. Centers for Disease Control and Prevention (CDC), "Methicillin-resistant Staphylococcus aureus, infections in correctional facilities-Georgia, California, and Texas", 2001-2003 MMWR Morb Mortal Wkly Rep, 52 (2003), pp. 992-996.

11. Millar BC, Loughrey A, Elborn JS, Moore JE, "Proposed definitions of community-associated meticillin-resistant Staphylococcus aureus (CA MRSA)", J Hosp Infect, 2007; Vol.67, No.2, pp. 109113.

12. Naimi TS, LeDell KH, Como-Sabetti $\mathrm{K}$, et al, "Comparison of community- and health care-associated methicillin resistant Staphylococcus aureus infection", JAMA, 2003; Vol. 290 , No. 22, pp. 2976-2984.

13. Cosgrove SE, Sakoulas G, Perencevich EN, Schwaber MJ, Karchmer AW and Carmeli Y, "Comparison of Mortality Associated with Methicillin-Resistant and 
Methicillin-Susceptible Staphylococcus aureus Bactermia: A Meta-Analysis", Clin Infect Dis, 2003; Vol. 36, No. 1, pp. 53-59.

14. Whitby M, McLaws ML and Berry G, "Risk of Death from Methicillin-Resistant Staphylococcus aureus Bacteremia: A Meta-Analysis", Med J Aust, 2001; Vol. 175, No. 5, pp. 264-267.

15. Baggett HC, Hennessy TW, Leman R, Hamlin C, Bruden D, Reasonover A, Martinez P, and Butler JC, "An outbreak of community-onset methicillinresistant Staphylococcus aureus skin infections in southwestern Alaska", Infect Control Hosp Epidemiol, 2003; Vol. 24, No. 6, pp. 397-402.

16. Begier EM, Frenette K, Barrett NL, Mshar P, Petit S, Boxrud DJ, Watkins-Colwell K, Wheeler S, Cebelinski EA, Glennen A, Nguyen D, and Hadler JL, "A highmorbidity outbreak of methicillinresistant Staphylococcus aureus among players on a college football team, facilitated by cosmetic body shaving and turf burns", Clin. Infect. Dis, 2004; Vol. 39, No. 10, pp. 1446-1453.
17. Campbell KM, Vaughn AF, Russell KL, Smith B, Jimenez DL, Barrozo CP, Minarcik JR, Crum NF, and Ryan MA, "Risk factors for community-associated methicillin-resistant Staphylococcus aureus infections in an outbreak of disease among military trainees in San Diego, California, in 2002", J. Clin. Microbiol, 2004; Vol. 42, No.9, pp. 4050-4053.

18. Centers for Disease Control and Prevention (2003), "Outbreaks of community-associated methicillinresistant Staphylococcus aureus skin infections-Los Angeles County, California, 2002-2003”, Morb. Mortal. Wkly. Rep. 52:88.

19. Stevens DL, Bisno AL, Chambers HF, Everett ED, Dellinger P, Goldstein EJ et al., "Practice guidelines for the diagnosis and management of skin and soft tissue infections", Clin Infect Dis, 2005; Vol.41, No.10, pp.1373-406.

20. Deresinski S, "Methicillin-resistant Staphylococcus aureus: an evolutionary, epidemiologic and therapeutic odyssey", Clin Infect Dis, 2005; Vol.40, No.4, pp.562573.

21. Kheder SI, Eltayeb I, Shaddad SAI and Kheder E, "Effect of Antibiotic Rotation Protocol on the Development of Hospital Acquired Infections in Hospital Surgical Units in Sudan”, Sudan Medical Monitor, 2010; Vol. 5, No. 4, pp. 165-173.

\section{How to cite this article:}

Subhra Saha et al (2018) 'Increasing Incidence of Multidrug Resistance Among CA-MRSA Causing Skin and Soft Tissue Infections: A Case Series', International Journal of Current Advanced Research, 07(4), pp. 11970-11973.

DOI: http://dx.doi.org/10.24327/ijcar.2018.11973.2091 